1st International Conference - Global Ethics - Key of Sustainability (GEKoS) | May 15th, 2020 | Bucharest, Romania

\title{
Implementation of the Integrated Management System for Quality - Food Safety - Development Strategy for the Dobrogea Tourism Service
}

\author{
Valentina Irena TUDORAN (NICULIȚĂ), Oana OPRIŞAN, \\ Ana Maria DUMITRACHE (ŞERBĂNESCU)
}

https://doi.org/10.18662/lumproc/gekos2020/24

How to cite: Tudoran (Niculiţă), V.I., Oprişan, O., \& Dumitrache (Şerbănescu), A.M. (2020). Implementation of the Integrated Management System for Quality - Food Safety - Development Strategy for the Dobrogea Tourism Service. In A. Grigorescu \& V. Radu (vol. ed.), Lumen Proceedings: Vol. 11. 1st International Conference Global Ethics - Key of Sustainability (GEKoS) (pp. 236-245). Iasi, Romania: LUMEN Publishing House.

https://doi.org/10.18662/lumproc/gekos2020/24 


\title{
Implementation of the Integrated Management System for Quality - Food Safety - Development Strategy for the Dobrogea Tourism Service
}

\author{
Valentina Irena TUDORAN (NICULIŢA $\breve{A})^{1}$, Oana OPRIŞAN ${ }^{2} *$ \\ Ana Maria DUMITRACHE (ŞERBĂNESCU) ${ }^{3}$
}

\begin{abstract}
Dobrogea is a place filled with beauty, tradition, and history, a place filled with significant potential regarding touristic services, potential which unfortunately is currently far from being reached. In order to be competitive on the national and international level, the tourism entrepreneurs in Dobrogea (the Constanta and Tulcea counties) should set as their main objectives the improvement of the quality of their touristic services, and the diversification of their offering. When referring to the quality of the touristic services, we focus on the quality of the services delivered by the touristic hospitality structures with lodgings, the quality of food services, and the quality of the services offered by all the other structures within this sector of the economy (travel agents, museums, transportation companies, commercial locations, etc.). At the same time, we note that tourism in Dobrogea is mainly seasonal, which leads to most investors hiring relatively lowskilled personnel, resulting in low quality services. Given the above, we aim to present and highlight several avenues for improvement of the touristic services' quality, several development opportunities for the sector, focusing on ensuring the customers' satisfaction.
\end{abstract}

Keywords: Quality Management; hotel industry; hospitality markets; quality services.

\footnotetext{
1 Bucharest University of Economic Studies, Romania, e-mail address: irenaniculita@yahoo.com

${ }^{2}$ Ovidius University of Constanta, Romania, e-mail address: oana.oprisan@yahoo.com

3 Bucharest University of Economic Studies, Romania, e-mail address: a.mariadumitrache@yhoo.com

* Corresponding author. oana.oprisan@yahoo.com

(C) The Authors, LUMEN Conference Center \& LUMEN Proceedings.

Selection and peer-review under responsibility of the Organizing Committee of the conference
} 


\section{Introduction}

Any private organization is created with the purpose of generating profit for investors; however, the effective implementation of integrated management systems is geared towards the long-term development of the business, as well as the improvement of the organization's global performance.

The implementation of an integrated quality-food safety management system in conformity with the newly revised ISO standards (EN ISO 9001:2015, EN ISO 22000:2018) represents a concrete and viable tool for achieving the desiderate for the development of a sustainable economy in Europe [10].

The achievement of the intended results, the knowledge of internal and external threats, the prevention or reduction of unwanted effects, as well as the obtaining of desired effects determine a safe and solid long-term development of the organization, through the consistent offering of high quality products and services, with an efficient and reduced consumption of resources, without affecting neither the quality of the surrounding environment nor the consumers' health.

Why the tourism services in Dobrogea?

Dobrogea is a place filled with beauty, tradition and history, a place with a significant potential in terms of tourism services.

The Danube Delta remains the fairytale land between the Danube and the sea, where any tourist wants to get.

The main objectives of the paper are:

The presentation of theoretical notions referring to tourism, management systems in the field of quality, food safety, the benefits of implementing integrated systems and their contribution to the firm's competitivity.

The highlighting of various characteristics of the integrated qualityfood safety management system in the tourism services sector, especially for tourism in Dobrogea.

The elaboration of proposals and recommendations for the improvement of tourism firms' competitivity, starting from the conclusions of the study on implementing quality systems within tourism services in Dobrogea. 


\section{Literature review}

It can be said that the level of tourism services quality is determined by two essential components, namely: a quantitative component, mainly material, representing the equipment and technology available to the operator, the food served at restaurants, the decorum, the manner in which the services are offered; and a qualitative, behavioral, component. [2].

The implementation of the integrated quality - food safety management system assumed the implementation of a management system based on two references: ISO 9001:2005 and ISO 22000:2018.

An integrated quality - food safety management system represents a logical and systematic managerial approach; this allows the taking of optimum strategic and operational decisions which account for all the essential aspects leading to the efficient functioning of an organization, from a quality standpoint as well as from that of food safety and hygiene etc. [3]

ISO 9001:2015 brings important modifications to ISO 9001:2008, its adopted structure and terminology being in conformity with the SL Annex of the ISO Directives - High Level Structure (HLS). [10]

The need to revise the ISO 9001:2008 standard appeared due to the following considerations [10]:

- The adoption of the SL Annex (High Level Structure) and its terminology;

- A better applicability for service-providing organizations, given they must quickly adapt to the changes determined by globalization, sustainable development, technological progress, the dynamics of client requirements, etc.;

- The introduction of new concepts on quality and management;

- The integration with other management system standards (environment, information security, etc.);

- The use of revised quality principles.

In addition to the previous edition (whose implementation and certification demonstrated the capability of an organization to consistently supply products which satisfy the client's requests and legal requirements, as well as the organization's commitment to improving customer satisfaction), the ISO 9001:2005 standard establishes explicit requirements for the observing of the risks and opportunities associated with the organizational context and the objectives established by the organization with the purpose of the long-term development of the business, as well as the achievement of the desiderate for sustainable development [10]. 
One of the main objectives of a quality management system based on risk-aware thinking is to act as a prevention instrument, fact due to which the current edition of the standard has eliminated the 'preventive action' requirements. At the same time, the risk-aware thinking adopted by ISO 9001:2015 allows for the reduction of normative requirements and their replacement with performance requirements, for a greater flexibility of requirements on processes, documented information and organizational responsibilities. [10]

The Global Initiative for Food Safety has identified four different targets, which can be the object of certifications in the agro-foods field (agriculture, food industry, and alimentation): food safety, food quality, food protection and the avoidance of food fraud. [8]

The ISO 22000:2018 standard (published 19 ${ }^{\text {th }}$ June 2019) reunites the following key elements for ensuring food safety: the HACCP principles, management system, preliminary programs, and interactive communication [8]. The transition period from the first edition, 2005, to the current one is of 3 years from its publication i.e. June 2022.

In the tourism services sector, as in any other sector of the economy, reaching the desired level of quality implies not only the implementation and certification of the aforementioned quality systems (even of other management systems, such as: environment, occupational security etc.), but also the satisfaction of the requirements of clients and of all other partners. As such, the ensuring of touristic products and services' competitivity must be based on quality management or any other integrated management system which includes the management of quality [2; 9].

Any integrated management system implemented at the level of an organization which functions in the tourism services sector, or any other sector, is based on the Quality assurance policy elaborate by the respective organization's top management [6].

\section{Research methodology}

Given the theme of this paper, throughout the research we've resorted to analysis, which allowed us to highlight numerous theoretical and practical elements regarding the contribution of integrated quality-food safety management systems implemented in the tourism services in Dobrogea to their development.

Starting from the results of said research we have elaborated proposals and recommendations for the improvement of the quality of 
tourism services in Dobrogea, which can also be applied to the tourism sector of other Romanian regions.

\section{Results}

The Dobrogea of today spans between the Danube and the Black Sea, consisting of the Constanta and Tulcea counties, from an administrative and territorial point of view.

If we are referring to Southern Dobrogea (Constanta county), we have in mind seaside tourism, rural tourism, urban, hot baths, business, cultural, religious, eco-tourism, niche tourism etc. Among the touristic attractions in Southern Dobrogea we mention [4]:

- The Agigea "Dunele Marine" (Marine Dunes) ;

- The Adamclisi Tropaeum TraianiMonument;

- The Hagieni forest (natural reservation, where one can meet, among the shrubs or limestone plateaus, horned vipers or other venomous snakes);

- The Buried Church of Histria;

- The Histria stronghold;

- The town of Techirghiol, with their well-known 'black gold' (silt) Techirghiol lake;

- The city of Mangalia (Callatis), where one can visit the touristic harbor and the streets with churches and mosques, as well as old houses belonging to people of various ethnicities;

- The Black Sea seaside, going down from Navodari to VamaVeche;

- The city of Constanta, with its well-known Genoese Lighthouse, the Hunchiar Mosque, the Casino Promenade, the Casino (currently under rehabilitation works), the Tomis touristic port, the Aquarium, the Dolphinarium and Planetarium, the Aqua Magic aqua park, as well as several representative museums for the history and culture of Dobrogea;

- The Siutghiol Lake, and the Ovidiu Island;

- The Murfatlar, Rasova vineyards, etc.

"Northern Dobrogea (Tulcea county) and the Danube Delta are unique in Europe and Romania, its territory containing: the oldest geological formations on the continent (the Macinului Mountains, the Casimcea plateau), neighboring the newest land - the Danube Delta; the largest 
spanning surface of protected areas and Natura 2000 sites in Romania, and one of the largest in the European Union, represented by steppe and seaside bioregions; the endemic sub-Mediterranean and Balkan forest - including the largest linden forest in Europe; the widest compact surface of reeds in the world; the sand dunes with their characteristic coast flora, which forms the longest unaltered coast in Southeastern Europe." [1]

Among the main tourist destinations of Northern Dobrogea, aside from those mentioned above, we can find:

- The Dobrogea Keys geological reservation, where we can find the Casian lake, the Casian cave, and the Casian monastery;

- The bats' cave, and the 'La Adam' Cave;

- The Babadag forest, where one can find numerous species of plants and animals protected by law, among which we mention wild orchids;

- The town of Ibida, near the town of 'Slava Rusă';

- The Iacobdeal lake, near Turcoaia;

- The town of Dinogetia;

- The town of Enisala or Heracleea;

- The town of Histria;

- Jurilovca, the town of Arganum, cape Dolojman;

- Tulcea, Murighiol, Agighiol.

After the analysis of the results of numerous studies regarding tourism in Dobrogea, as well as after discussions with several tourism operators in the counties of Constanta and Tulcea, we can say that, as time passed, tourists become more demanding regarding hospitality and restaurant conditions, as well as regarding the 'wealth' of the destination (cultural authenticity, traditions, knowledge of aspects regarding the flora, fauna, special ecosystems, environmental protection, etc.).

Tourists want their hosts to make them feel comfortable, welcome, a part of the community they are visiting; they expect the guides to be well prepared and with good communication abilities; to find different offers of recreation; to have the possibility of purchasing high quality traditional products or those which are specific to the area they are visiting.

Unfortunately, numerous of the aforementioned tourist attractions are not characterized by positive reviews regarding the quality of the supplied products and/or services, they do not have an attractive offer. On numerous occasions, there is no cooperation or communication between the 
managers of the protected areas and the private sector; all of the above leading to low quality products and services [1].

Regarding the quality of the products and services within hotels and bed-and-breakfasts, the situation is improved. Most investors within the sector have emphasized quality assurance, the implementation of different standards specific to tourism [7], as well as that of quality management systems or that of the integrated quality-food safety management system.

It can be said that the benefits of implementation of quality systems within tourism organizations (hotels, bed-and-breakfasts, tourism agencies, transport operators etc.) are [9; 6]:

- Lowering costs through the improvement of systems and processes;

- The realization of products and services which constantly fulfil the needs and expectations of clients;

- The improvement of clients' satisfaction, through the improvement of the safety and quality of the supplied products and services;

- The improvement of employee confidence, as well as that of top management, in their own management system.

On the other hand, when looking at the services offered by restaurants, about the quality of the foods, the reviews are not always positive. Most restaurants on the coast, as well as many in Northern Dobrogea, have a seasonal schedule, with employees not usually properly trained, in insufficient numbers during peak periods. Numerous times, the firms' managers are not preoccupied with supplying products and services which completely satisfy the clients' demands; all of the above lead to barely satisfying results, not good, nor very good, let alone excellent.

One of the solutions for improving the restaurants' market competitiveness is the implementation of a food safety management system, together with one for quality. Among the advantages for the certification of the food safety management system we mention:

- The supplying of products safe for consumption;

- Reaching a high level of quality in the products and services, leading to more positive client reviews (usually, that is the reason why clients come back and/or recommend the restaurant and/or certain dishes);

- The efficient communication with clients and other interested parties along the supply chain;

- The conformity with the requirements specified in the standards or other regulatory documents regarding food quality and safety;

- Respecting their own food safety policies. 


\section{Proposals and recommendations}

Our recommendations for the Dobrogea touristic destination, based on the assessment of the current situation are: $[1 ; 5]$

- The intensification of the actions/preoccupations regarding the quality assurance of touristic products and services;

- The implementation by increasing numbers of tourism operators of standards specific to tourism, as well as of quality management systems or of integrated quality - food safety management systems;

- The intensification of promotion actions for touristic destinations in Dobrogea;

- The focusing on the organization of recreational tourism activities (prioritizing the short term organized and ad-hoc tourism, with lodging at the final destination), with secondary emphasis on commercial and professional tourism;

- The priority focus on the external tourism market (especially the European one), with secondary emphasis on the internal market;

- The capitalization on the existing potential for practicing traditional tourism forms (rest, relaxation), as well as more specialized forms (sport fishing, cultural, religious, scientific tourism), rural tourism, heliomarine courses, etc.;

- The development of programs for cultural and national patrimony tourism, landscape tourism, the diversification of free time activities at the destination (hikes, boat rides, sport fishing, various crafts, etc.);

- Exploring the Danube Delta in a 'slow manner', given the need to protect the natural patrimony, cultural and patrimony values, to respect the communities, environment and local traditions;

- The focus on niche tourism.

\section{Conclusions}

In order to be competitive on the market, any tourism operator must be preoccupied with satisfying the clients' needs, by the permanent and constant growth of the offered goods and services' quality. This fact is possible only through the close monitoring of the standards specific to 
touristic services, as well as the systems for the management for quality, food safety, occupational safety, environmental, etc.

The integration of two or more management systems in an integrated management system can have the following advantages [3]:

- The simplification of the already existing management systems, in case they are already implemented, or even certified;

- The improvement of the benefits brought not only to the organization, but also to the clients, by each management system;

- The optimization of the consumption of utilized resources;

- The reduction of the costs of implementation, certification, monitorization of several management systems;

- The establishment of a unique framework for the continuous improvement of all standards;

- The definition of a single Quality policy, which is to include aspects regarding all the implemented management systems;

- Establish the priorities and decide the general and individual objectives;

- Create all the conditions for planning, control, monitoring activities, corrective actions, audit and analysis;

- Identify the industry's relevant regulations;

Thusly create a greater capability to adapt to changes in the market, client demands, new trends etc.

\section{References}

[1] Consiliul Județean Tulcea, Plan Strategic pentru Dezvoltarea Turismului Durabil în Delta Dunării, Document inițiat în cadrul Proiectului «Dezvoltarea Potențialului pentru un Turism Durabil într-o zonă umedă Natura 2000: Studiu de caz Delta Dunării» - Roe/041/06 şi finalizat în Mai 2009; 2009. Available from:

http://www.ddbra.ro/media/Plan\%20strategic\%20turism\%20DD Mai\%2020 09.pdf [accessed at 10 April 2020]

[2] Cristea AA. Reconsiderarea sistemului de calitate a serviciilor din industria hotelieră românescă - premisă a creşterii competitivității ofertei de turism, Revista Amfiteatru Economic, Vol. XI, nr. 26, Iunie; 2009. Available from: https://www.amfiteatrueconomic.ro/temp/Articol 886.pdf [accessed at 24 April 2020]

[3] Ecofin Consult, 2020, Available from:
http://www.ecofinconsult.md/ro/home/140 
[4] Idei pentru vacanta Available from: https://ideipentruvacanta.ro/15-atractiidin-judetul-constanta/ [accessed at 27 April 2020]

[5] Ministerul Dezvoltării Regionale şi Administrației Publice. Strategia Naţională pentru Dezvoltare Regională 2014-2020; 2013: 119-138. Available from: http://www.inforegio.ro/images/Documente de programare/Strategia Natio nala Dezvoltare Regionala - iulie 2013.pdf. [accessed at 10 April 2020]

[6] Olaru M. Managementul calității. Bucureşti: Editura Economică; 1999.

[7] Rondelli V, Cojocaru S. Managementul calității serviciilor din turism şi industria ospitalității. Bucureşti: Editura THR-CG; 2004.

[8] SRAC; 2020. Available from: https://www.srac.ro/ro/siguranta-alimenteloriso-22000 [accessed at 14 April 2020]

[9] Stănescu D, Mihail Ş, Stan R. Calitatea în serviciile turistice. Bucureşti: Editura Universitară; 2009.

[10] SUN CERT; 2020. Available from: https://suncert.ro/certificari/sistemeintegrate/ [accessed at 14 April 2020] 